\title{
PENGARUH KESELAMATAN DAN KESEHATAN KERJA, KOMPENSASI, DAN MOTIVASI KERJA TERHADAP KINERJA KARYAWAN CV BERKAH ANUGERAH ABADI KABUPATEN BANJAR PROVINSI KALIMANTAN SELATAN
}

\author{
Hernilawati $^{1 \text {, }}$, Sutriswanto ${ }^{2)}$, Devi Rusvitawati ${ }^{3)}$ \\ 12) Pascasarjana, Universitas Merdeka Malang \\ ${ }^{3)}$ Manajemen, STIMI Banjarmasin \\ Jln. Terusan Dieng No. 62-64 Klojen, Pisang Candi, Kec. Sukun, Malang \\ ${ }^{1)}$ hernilaw736@gmail.com
}

\begin{abstract}
Abstrak
Tujuan penelitian untuk menganalisis dan mengetahui pengaruh keselamatan dan kesehatan kerja, kompensasi, dan motivasi kerja terhadap kinerja karyawan pada CV Berkah Anugrah Abadi Kertak Hanyar.Metode penelitian kuantitatif digunakan dalam penelitian. Populasi adalah semua anggota karyawan adalah 63 karyawan. Teknik pengambilan sampel adalah sensus yaitu seluruh populasi dijadikan sampel yaitu sampel pada penelitian ini 63 responden. Teknik pengumpulan data menggunakan kuesioner. Analisa data menggunakan dengan analisis regresi linier berganda. Hasil penelitian menunjukkan bahwa keselamatan dan kesehatan kerja, kompensasi, dan motivasi kerja berpengaruh signifikan terhadap kinerja secara parsial pada CV Berkah Anugrah Abadi Kertak Hanyar. Secara simultan atau bersama-sama, keselamatan dan kesehatan kerja, kompensasi, dan motivasi kerja berpengaruh signifikan terhadap kinerja pada CV Berkah Anugrah Abadi Kertak Hanyar.
\end{abstract}

Kata kunci: Kinerja, Keselamatan dan kesehatan kerja, kompensasi, dan motivasi kerja

\begin{abstract}
The research objective was to analyze and determine the effect of occupational safety and health, compensation, and work motivation on employee performance in CV Berkah Anugrah Abadi Kertak Hanyar need the research. The quantitative method is used in the research. The population is all members of the employee which are 63 employees. The technique of sampling is a census, in which 63 respondents become the sample. The data collection technique is a questionnaire. Data is analyzed by linear regression analysis. The results showed that occupational safety and health, compensation, and work motivation partially had a significant effect on performance $C V$ Berkah Anugrah Abadi Kertak Hanyar. The results showed that occupational safety and health, compensation, and work motivation partially had a significant effect on performance CV Berkah Anugrah Abadi Kertak Hanyar
\end{abstract}

Keywords: Performance, Work safety and health, compensation, and work motivation

\section{PENDAHULUAN}

Indonesia menjadi salah satu negara yang mempunyai beraneka ragam kekayaan alam. Keyayaan alam yang berlimpah merupakan modal dalam pembangunan nasional. Sumber daya alam tersebut salah satunya berasal dari sektor pertambangan. Industri Pertambangan berkembang dengan pesat sejalan dengan bertambahnya permintaan konsumen, baik untuk memenuhi kebutuhan primer maupun sekunder.

Salah satu perusahaan yang bergerak di bidang pertambangan batu bara adalah CV Berkah Anugerah Abadi Kertak Hanyar Kabupaten Banjar Provinsi Kalimantan Selatan. Usaha pertambangan Berkah Anugerah Group melalui CV Berkah Anugerah Abadi (BAA) mengembangan usaha pertambangan dengan kerja sama dengan pemilik IUP - OP yang saling menguntungkan. Tahun 2008 CV BAA melakukan investasi di perijinan lahan tambang dimana bekerja sama dengan PT Mitra Jaya Abadi Bersama yang menemukan lahan tambang potiensial, bersama-sama mengurus perijinan kuasa pertambangan di mana seluruh pendanaan pembuatan ijin kuasa pertambangan tersebut berasal dar CV BAA dan PT Mitra Jaya Abadi Bersama 
bertanggung jawab mengurus perijinan tersebut dengan dasar surat surat perjanjian kerja sama pertambangan. Program Berkah Anugerah Group mulai tahun 2013 adalah pelaksanaan take over 2 IUP-OP yang potensial di Wilayah Kalimantan Tengah.

Pekerja tambang beresiko tinggi menderita penyakit akibat kerja (PAK) dan kecelakaan kerja (KK). Beberapa penelitian menyebutkan bahwa para pekerja tambang sangat rentan mengalami pneumokoniosis. Seperti dilansir depkes.go.id pada 13 November 2015, sebuah riset menunjukkan, sekitar 9 persen penambang batu bara di Indonesia menderita pneumoconiosis (Safetysign, 2016).

Menurut Organisasi Perburuhan Internasional (ILO), pneumokoniosis merupakan penyakit akibat kerja (PAK) paling banyak diderita oleh pekerja. Tahun 2013, 30 persen hingga 50 persen pekerja di negara berkembang menderita pneumokoniosis. Sedangkan data dari Organisasi Kesehatan Dunia (WHO) menyebutkan, dari 1 juta kematian pada pekerja, 5 persen di antaranya adalah akibat Pneumokoniosis (Safetysign, 2016).

Tingkat kecelakaan yang tinggi dalam bekerja maka mengkibatkan karyawan banyak yang menderita, absensi meningkat, produksi menurun, dan biaya pengobatan semakin besar. Ini semua akan menimbulkan kerugian bagi karyawan maupun perusahaan bersangkutan, karena mungkin karyawan terpaksa berhenti bekerja sebab cacat dan perusahaan kehilangan karyawannya.

Keselamatan dan kesehatan kerja (K3) merupakan suatu upaya untuk menciptakan suasana bekerja yang aman, nyaman, dan tujuan akhirnya adalah mencapai kinerja yang maksimal. Oleh karena itu, K3 mutlak untuk dilaksanakan pada setiap jenis bidang pekerjaan tanpa kecuali. Upaya K3 diharapkan dapat mencegah dan mengurangi risiko. Karyawan yang terjamin keselamatan dan kesehatan kerjanya akan bekerja lebih optimal, dan ini akan berdampak pada produk yang dihasilkan. Pada gilirannya, ini akan meningkatkan kualitas produk dan jasa yang dihasilkan ketimbang sebelum dilakukan penerapan, citra organisasi terhadap kinerjanya akan semakin meningkat, dan meningkatkan kepercayaan pelanggan.

Proses penerapan sistem manajemen K3 harus dimulai dari manajemen puncak dalam perusahaan. Sebagai tahap pertama adalah memilih jenis sistem manajemen K3 yang akan diterapkan. Organisasi harus mempersiapkan sendiri untuk memenuhi persyaratan sistem manajemen K3 yang dipilih. Penetapan tujuan penerapan sistem manajemen K3 harus dinyatakan secara jelas oleh manajemen puncak. Mereka dapat membuat surat edaran atau spanduk yang nantinya disosialisasikan pada semua personel di perusahaan. Disamping tujuan penerapan sistem manajemen K3, surat edaran ini juga menyatakan ruang lingkup penerapan sistem manajemen K3 (Sedarmayanti, 2009).

Variabel penting lain yang perlu dipehatikan dalam organisasi atau perusahaan adalah kompensasi. Pekerjaan yang memerlukan tingkat kesukaran yang tinggi dan resiko yang berat, perlu kompensasi yang tinggi. Karyawan diberikan penghargaan finansial dan non finansial oleh organisasi berdasarkan tugas, pekerjaan, dan hasil pekerjaan yang telah telah dicapai. Kompensasi bisa berbentuk gaji, pemberian hari libur, dan bonus. Kompensasi diberikan sesuai dengan kinerja pegawai. Kinerja yang dicapai sesuai dengan kompensasi yang diberikan organisasi.

Kompensasi merupakan sistem yang mampu menjamin kepuasan para anggota organisasi yang pada gilirannya memungkinkan organisasi memperoleh, memelihara, dan mempekerjakan sejumlah orang yang dengan yang memiliki sikap dan perilaku positif bekerja dengan produktif untuk kepentingan organisasi (Siagian, 2008: 253).

Selain itu faktor motivasi juga penting ditingkatkan dalam organisasi. Karyawan harus selalu dimotivasi agar kinerja yang dihasilkan meningkat. Sebab kejenuhan bekerja sering terjadi di tempat kerja. Apabila gejala ini terjadi pada diri karyawan, dapat dilihat ciri-cirinya seperti absensi (ketidak hadiran) meningkat, disiplin merosot, produktivitas menurun, labour turn over (tingkat keluar masuk karyawan) makin tinggi, ada tuntutan karyawan yang tidak henti-hentinya, sampai pada gejala pemogokan (Alma, 2008: 202).

Motivasi berhubungan langsung dengan kinerja karyawan. Motivasi dapat dipastikan mempengaruhi kinerja, walaupun bukan satu-satunya faktor yang membentuk kinerja (Wibowo, 2011: 389). Kebutuhan adanya kekurangan fisiologis atau psikologis yang menimbulkan perilaku.Teori motivasi berdasarkan hirarki kebutuhan dikemukakan Maslow menyatakan bahwa 
kebutuhan manusia berjenjang dari psysiological, safety, social, dan self actualization (Wibowo, 2011: 391).

Motivasi kerja berkenaan dengan bagaimana cara mendorong orang bersemangat bekerja, agar mau bekerja dengan memberikan secara optimal kemampuan dan keahliannya untuk mencapai tujuan organisasi. Motivasi penting dalam peningatan kinerja karyawan karena dengan motivasi diharapkan agar setiap karyawan mau bekerja keras dan antusias untuk meningkatkan kinerja dalam rangka pencapaian tujuan organisasi secara optimal. Karyawan akan mendapatkan imbalan yang sebanding dengan hasil kerja yang dikontribusikannyan kepada pihak organisasi (Sunyoto, 2012).

\section{TINJAUAN PUSTAKA}

\subsection{Kinerja}

Kinerja adalah pegawai atau karyawan adalah hasil kerja perorangan dalam sebuah organisasi (Hafied, 2016: 84). Kinerja adalah pekerjaan yang dapat dikerjakan oleh pekerja sesuai dengan tugas dan fungsinya. Kinerja adalah hasil kerja yang dapat ditampilkan seorang karyawan. Kinerja seorang karyawan dapat diukur dari hasil kerja, hasil tugas, atau hasil kegiatan dalam kurun waktu tertentu (Notoatmodjo, 2009).

Kinerja merupakan suatu keberhasilan yang dicapai oleh karyawan. Priansa (2014) menyebutkan bahwa kinerja adalah tingkat keberhasilan pegawai dalam menyelesaikan pekerjaannya dalan periode waktu tertentu dalam sebuah organisasi.

Kinerja adalah prestasi kerja atau hasil kerja baik kualitas maupun kuantitas yang dicapai Sumber Daya Manusia periode waktu dalam melaksanakan tugas kerjanya sesuai dengan tanggung jawab yang diberikan kepadanya (Zeanuri, 2015). Robbins (2000: 201) menegaskan bahwa kinerja merupakan suatu hasil yang dicapai oleh pekerja dalam pekerjaan tertentu menurut kriteria yang berlaku untuk suatu pekerjaan dalam suatu organisasi. Pengertian ini mengacu pada perbandingan antara hasil dan kriteria yang ditetapkan organisasi. Perbandingan yang diharapkan hasilkerja sesuai dengan kriteria atau melebihi kriteria yang ditetapkan.

Jadi kinerja adalah hasil kerja yang dapat ditunjukkan pekerja sesuai sesuai dengan tugas dan pekerjaannya dalam waktu tertentu di dalam sebuah organisasi. Hasil kerja yang diperoleh pekerja kemudian dibandingkan dengan kriteria yang ditetapkan oleh organisasi tempat karyawan bekerja.

\subsection{Keselamatan dan Kesehatan Kerja}

Menurut Yuniarsih dan Suwatno (2008) keselamatan kerja adalah kondisi aman atau selamat dari penderitaan, kerusakan, atau kerugian di tempat kerja. Resiko keselamatan di tempat kerja dapat menyebabkan kebakaran, tersengat aliran listrik, terpotong, luka, keselo, patah tulang, gangguan pengliohatan dan pendngaran. Sedangkan kesehatan kerja menunjukkan kondisi yang bebas dari gangguan fisik, mental, emosi atau rasa sakit yang disebabkan oleh lingkungan kerja.

Manajemen keselamatan dan kesehatan kerja merupakan upaya mempertahankan keselamatan dan kesehatan kerja pekerja dalam melakukan pekerjaan dalam perusahaan. Pekerja tidak mengalami ganguan kerja selama melaksanakan tugas yang dibebankan perusahaan atau lembaga tertentu. Pemeliharaan keselamatan, kesehatan fisik dan mental dilakukan selama pekerja masih mempunyai hubungan kerja dengan perusahaan atau kembaga teretntu (Sedarmayanti, 2009).

Tujuan dilakukan pemeliharaan kesehatan dan keselamatan kerja adalah agar pekerja mendapat jaminan kesehatan dalam bekerja sehingga dapat mencapai produktivitas kerja yang efektif. Tujuan jaminan keselamatan kerja adalah agar para pekerja bebas dari kecelakaan akibat kerja atau gangguan-gangguan lain yang dapat menurunkan produktivitas kerja (Notoatmodjo, 2000:)

\subsection{Kompensasi}


Marnis (2014) menyebutkan bahwa kompensasi merupakan semua pendapatan yang berbentuk uang atau barang langsung atau tidak langsung yang diterima karyawan sebagai imbalan atas jasa yang diberikan kepada perusahaan. Besarnya kompensasi (balas jasa) telah ditentukan dan diketahui sebelumnya, sehingga karyawan secara pasti mengetahui besarnya penerimaan kompensasi yang akan diterimanya.

Program kompensasi penting diperhatikan oleh organisasi dalam rangka mempertahankan sumber daya yang profesional dan berkualitas. Kompensasi merupakan semua imbalan yang diterima karyawan sebagai balas jasa untuk kerja mereka. Pada umumnya balas jasa terdiri dari upah atau gaji, tunjangan perusahaan, kesehatan, hari tua, insentif, dan premi (Kasmir, 2011).

Kompensasi mengandung arti yang lebih luas dari pada upah atau gaji. Upah atau gaji lebih menekankan pada balas jasa yang bersifat finansial, sedangkan kompensasi mencakup balas jasa finansial maupun non-finansial. Kompensasi merupakan pemberian balas jasa, baik secara berlangsung berupa uang (finansial) maupun tidak langsung berupa penghargaan (non-finansial) (Samsuddin, 2006).

Kompensasi adalah segala sesuatu yang diterima oleh karyawan sebagai balas jasa untuk kerja atau pengabdian mereka. Masalah kompensasi merupakan hal yang sangat kompleks, namun paling penting bagi karyawan maupun organisasi itu sendiri.Pemberian kompensasi kepada karyawan harus mempunyai dasar yang logis dan rasional (Notoadmodjo, 2009).

Kompensasi merupakan imbalan atau balas jasa yang diberikan oleh perusahaan kepada karyawannya yang dapat dinilai dengan uang. Kompensasi atau imbalan ini termasuk di dalamnya upah, gaji, insentif, komisi, dan sebagainya yang mengikat karyawan sehingga karyawan mau dan senang bekerja. Kompensasi ini harus menarik dan dapat menimbulkan keterikatan karyawan terhadap perusahaan, harus adil, harus dinamis, tidak kaku, harus dapat ditinjau kembali sesuai dengan prestasi karyawan (Alma, 2008).

Jadi kompensasi adalah semua pendapatan yang berbentuk uang atau barang langsung atau tidak langsung yang diterima karyawan sebagai imbalan atas jasa yang diberikan kepada perusahaan atau lembaga tertentu. Kompensasi adalah segala sesuatu yang diterima oleh karyawan sebagai balas jasa untuk kerja atau pengabdian mereka.

\subsection{Motivasi Kerja}

Motivasi adalah daya pendorong yang mengakibatkan seseorang atau keseluruhan bawahan mau dan rela mengerahkan kemampuan, keahlian, dan waktu untuk mengerjakan tugas yang menjadi tanggung jawabnya dalam rangka mencapai tujuan dan sasaran organisasi yang telah ditetapkan (Hafied, 2016).

Motivasi sering, diartikan dengan istilah dorongan, yang berarti tenaga yang menggerakkan jiwa dan jasmani untuk berbuat sehingga motif merupakan "driving force" seseorang, untuk bertingkah laku dalam mencapai tujuan yang telah ditetapkan. Setiap orang mempunyai motif diri yang berbeda antara orang yang satu dengan yang lainnya (Marnis, 2014).

Terry (Sedarmayanti, 2009) mendefisikan bahwa motivasi adalah keinginan yang terdapat pada seseorang atau individu yang merangsangnya untuk melakukan tindakan. Motivasi adalah suatu kekuatan yang dihasilkan dari keinginan seseorang untuk memuaskan kebutuhannya, misal; rasa lapar, haus, dan dahaga.

Motivasi adalah kekuatan kecendrungan seseorang atau individu melibatkan diri dalam kegiatan yang mengarah kepada pekerjaan tertentu. Pengertian motivasi menurut Terry adalah keinginan yang terdapat pada diri seseorang individu yang mendorongnya untuk melakukan perbuatan-perbuatan (perilaku) tertentu (Notoatmodjo, 2009).

Stooner mendefinisikan bahwa motivasi adalah sesuatu hal yang menyebabkan dan yang medukung tindakan atau perilaku seseorang (Notoatmodjo, 2009). Flippo (Notoatmodjo, 2009) merumuskan bahwa motivasi adalah suatu arahan pegawai dalam suatu organisasi agar mau bekerja sama dalam mencapai keinginan para pegawai dalam rangka pencapaian keberhasilan organisasi. 
Siagian (Sedarmayanti, 2009) menjelaskan bahwa motivasi adalah keseluruhan proses pemberian motivasi bekerja kepada bawahan sedemikian rupa sehingga mereka mau bekerja dengan ikhlas demi tercapainya tujuan organisasi dengan efisien dan ekonomis.

Motivasi adalah setiap usaha yang didasarkan untuk mempengaruhi perilaku seseorang dalam meningkatkan tujuan organisasi semaksimal mungkin. Motivasi mengacu pada dorongan dan usaha untuk memuaskan kebutuhan atau suatu tujuan (Notoatmodjo, 2009).

Jadi motivasi adalah keseluruhan proses pemberian motivasi bekerja kepada bawahan sedemikian rupa sehingga mereka mau bekerja dengan ikhlas. Upaya mencapai tujuan organisasi diharapkan dapat berjalan efisien dan ekonomis.

\subsection{Kerangka Konseptual Penelitian}

Berdasarkan uraian sebelumnya dapat dikemukakan model konsep penelitian ini sebagai berikut:

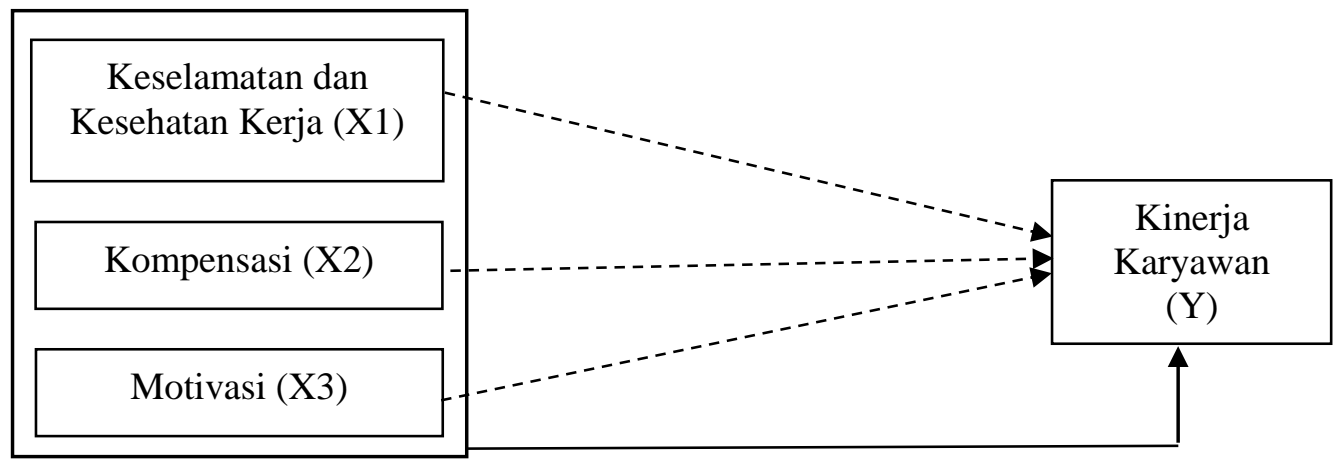

Keterangan:

Gambar Kerangka Konseptual Penelitian

$\longrightarrow$-....... Pengaruh Parsial

Pengaruh Simultan

\section{METODE PENELITIAN}

\subsection{Rancangan Penelitian}

Penelitian menggunakan metode ekspalanatif dengan teknik survey. Metode ini dilakukan untuk menganalisis hubungan kausal antara keselamatan dan kesehatan kerja, kompensasi, dan motivasi dengan kinerja. Hubungan kausal antara keselamatan dan kesehatan kerja, kompensasi, dan motivasi dengan kinerja yang menunjukkan pengaruh parsial dan simultan terhadap kinerja karyawan.

\subsection{Ruang Lingkup Penelitian}

Penelitian ini menganalisis pengaruh keselamatan dan kesehatan kerja, kompensasi, dan motivasi berpengaruh terhadap kinerja karyawan CV Berkah Anugerah Abadi Kertak Hanyar Kabupaten Banjar Provinsi Kalimantan Selatan. Selain itu penelitian ini juga menganalisis pengaruh kompensasi terhadap motivasi kerja. Keselamatan dan kesehatan kerja, kompensasi, motivasi kerja, dan kinerja merupakan ruang lingkup objek kajian manajemen sumber daya manusia (SDM).

\subsection{Variabel Penelitian}

\subsubsection{Definisi Konseptual Variabel}

1. Kinerja adalah pegawai atau karyawan adalah hasil kerja perorangan dalam sebuah organisasi (Hafied, 2016). Menurut Edison, Anwar, dan Komariyah (2017) dimensi untuk mengukur kinerja karyawan ada 4 dimensi. Keempat dimensi itu yaitu target, kualitas, waktu, dan taat asas. Target merupakan jumlah pekerjaan yang diselesaikan denganbaik. Kualitas merupakan hasil pekerjaan sesuai dengan standar mutu. Waktu berkaitan dengan ketepatan dan kecepatan mengerjakan pekerjaan. Taat asas adalah pekerjaan yang dilakukans esuai prosedur dan dapat dipertanggungjawabkan. 
2. Menurut Yuniarsih dan Suwatno (2008) keselamatan kerja adalah kondisi aman atau selamat dari penderitaan, kerusakan, atau kerugian di tempat kerja. Indikator pengukuran pelaksanaan Keselamatan dan kesehatan kerja aada dua yaitu preventif dan kuratuf. Upaya-upaya preventif dan promotif terkait dengan kesehatan dan keselamatan kerja ini antara lain dalam bentuk pemeriksaan kesehatan sebelum kerja (preplacement physical examination), pemeriksaan kesehatan secara berkala bagi karyawan, tersediannya kantin di lingkungan tempat kerja, terpeliharanya lingkungan kerja yang sehat, pencahayaan dan penerangan yang baik, kebisingan, penyejuk Tempat Kerja, bau-bauan, peralatan kerja, alat-alat pelindung diri. Pelayanan kuratif yang perlu diadakan di tempat kerja antara lain klinik dan psikolog (Notoatmodjo, 2009).

3. Marnis (2014) menyebutkan bahwa kompensasi merupakan semua pendapatan yang berbentuk uang atau barang langsung atau tidak langsung yang diterima karyawan sebagai imbalan atas jasa yang diberikan kepada perusahaan. Tiyanto (2010) juga menyebutkan bahwa kompensasi meliputi kompensasi langasung dan kompensasi tidak langsung. Kompensasi langsung seperti upah, gaji, komisi, bonuas, atau pembagian hasil. Kompensasi tidak langsung merupakan kompenasi yang diberikan pada saat karyawan tidak bekerja seperti liburan, istirahat, asuransi, bantuan pendidikan, dan rekreasi.

4. Motivasi adalah daya pendorong yang mengakibatkan seseorang atau keseluruhan bawahan mau dan rela mengerahkan kemampuan, keahlian, dan waktu untuk mengerjakan tugas yang menjadi tanggung jawabnya dalam rangka mencapai tujuan dan sasaran organisasi yang telah ditetapkan (Hafied, 2016: 31). Aspek yang diukur dalam motivasi kerja adalah kebutuhan fisiologi, kebutuhan rasa aman, kebutuhan berafiliasi, kebutuhan penghargaan, dan kebutuhan aktualisaasi diri (Notoatmodjo, 2007: 225).

\subsubsection{Definisi Operasional Variabel}

1. Kinerja adalah hasil kerja yang dapat ditunjukkan pekerja sesuai sesuai dengan tugas dan pekerjaannya dalam waktu tertentu dalam suatu organisasi. Pengukuran kinerja berdasarkan 4 dimensi itu yaitu target, kualitas, waktu, dan taat asas. Target merupakan jumlah pekerjaan yang diselesaikan denganbaik. Kualitas merupakan hasil pekerjaan sesuai dengan standar mutu. Waktu berkaitan dengan ketepatan dan kecepatan mengerjakan pekerjaan. Taat asas adalah pekerjaan yang dilakukans esuai prosedur dan dapat dipertanggungjawabkan.

2. Keselamatan kerja adalah kondisi aman atau selamat dari penderitaan, kerusakan, atau kerugian di tempat kerja. Preventif dan kuratif. Preventif meliputi pemeriksaan kesehatan sebelum kerja (preplacement physical examination), pemeriksaan kesehatan secara berkala bagi karyawan, tersediannya kantin di lingkungan tempat kerja, terpeliharanya lingkungan kerja yang sehat, pencahayaan dan penerangan yang baik, kebisingan, penyejuk Tempat Kerja, bau-bauan, peralatan kerja, alat-alat pelindung diri. Kuratif meliputi klinik dan psikiater.

3. Kompensasi adalah semua pendapatan yang berbentuk uang atau barang langsung atau tidak langsung yang diterima karyawan sebagai imbalan atas jasa yang diberikan kepada perusahaan atau lembaga tertentu. kompensasi terbagi menjadi dua macam. Pertama kompensasi finansial dan kedua kompensasi nofinansial. Kompensasi finansial dalam bentuk uang dan kompensasi nonfinansial berupa selain uang.

4. Motivasi kerja adalah keseluruhan proses pemberian motivasi bekerja kepada bawahan sedemikian rupa sehingga mereka mau bekerja dengan ikhlas. kebutuhan fisiologis, kebutuhan rasa aman, kebutuhan sosial, kebutuhan, penghargaan, dan kebutuhan aktualisasi dir.

\subsubsection{Jenis dan Sumber Data}

1. Jenis Data

Data penelitian ini tergolong data kuantitatif. Data penelitian ini merupakan data primer. Data primer adalah data yang diperoleh langsung kepada sumber 
data melalui penyebaran angket kepada karyawan CV Berkah Anugerah Abadi Kertak Hanyar Kabupaten Banjar Provinsi Kalimantan Selatan.

2. Sumber Data

Sumber data penelitian ini adalah karyawan CV Berkah Anugerah Abadi Kertak Hanyar Kabupaten Banjar Provinsi Kalimantan Selatan. Jumlah karyawan 103 orang.

\subsubsection{Uji Validitas dan Uji Reliabilitas}

Uji validitas dan reliabilitas angket ini dilakukan sebelum penelitian. Uji validitas dilakukan untuk memperoleh angket benar-benar dapat mengukur apayang ingin diukur dalam penelitian. Menurut Umar (2010) rumus yang digunakan untuk menganalisis uji validitas:

$$
r x y=\frac{\mathrm{N}(\Sigma \mathrm{XY})-(\Sigma \mathrm{X})(\Sigma \mathrm{Y})}{\sqrt{\{(\mathrm{N} \Sigma \mathrm{X} 2-(\Sigma \mathrm{X}) 2\}\{(\mathrm{N} \Sigma \mathrm{Y} 2-(\Sigma \mathrm{Y}) 2\}}}
$$

$\mathrm{r}_{\mathrm{xy}} \quad=$ koefisien korelasi

$\sum X=$ jumlah skor total

$\sum Y=$ jumlah skor total (seluruh item)

$\mathrm{n} \quad=$ jumlah responden

Perhitungan uji validitas dengan menggunakan korelasi product Moment menggunakan program SPSS Versi 21.

Uji reliabelitas dilakukan pada butir-butir instrumen untuk mengetahui keandalannya. Perhitungan dilakukan dengan menggunakan koefisien alpha dari Cronbach minimal 0,6. (Sugiyono, 2008). Uji reliabelitas instrument dilakukan dengan teknik belah dua (split half). Butir pertanyaan ganjil dipisah dengan butir pertanyaan genap sehingga didapatkan dua kelompok butir pertanyaan. Kemudian dianalisis dengan menggunakan korelasi product moment. Hasil perhitungan korelasi dihitung kembali dengan menggunakan rumus Spearman Brown (Umar, 2010: 55).

\subsubsection{Populasi dan Sampel}

Populasi penelitian ini adalah semua karyawan CV Berkah Anugerah Abadi Kertak Hanyar Kabupaten Banjar Provinsi Kalimantan Selatan pada pertambangan yang berjumlah orang 103 orang. Menurut Wahyuni (2011) sampel penelitian adalah bagian dari populasi yang menjadi objek penelitian. Teknik pengambilan sampel menggunakan metode sensus, artinya semua populasi dijadikan sampel penelitian berjumlah 103 orang.

\subsubsection{Teknik Pengumpulan Data}

Pengumpulan data merupakan pencatatan peristiwa atau karakteristik sebagian atau seluruh elemen populasi penelitian. Pengumpulan data penelitian dapat dilakukan dengan beberapa cara atau teknik pengumpulan data. Teknik pengumpulan data penelitian ini menggunakan Kuisioner. Kuisioner adalah cara pengumpulan data dengan menggunakan daftar pertanyaan (angket) atau daftar isian tentang objek yang diteliti (populasi atau sampel ) (Misbahuddin dan Hasan, 2013).

\subsubsection{Teknik Analisa Data}

Analisis data penelitian ini menggunakan analisis regresi linier ganda. Regresi berganda merupakan analisis yang digunakan untuk mengetahui pengaruh variabel bebas terhadap variabel terikat. Penelitian ini juga menganalisis deksripsi atau gambaran keselamatan dan kesehatan kerja, kompensasi, motivasi kerja, dan kinerja karyawan CV Berkah Anugerah Abadi Kertak Hanyar Kabupaten Banjar Provinsi Kalimantan Selatan.

\section{Analisis Deskriptif}


Keselamatan dan Kesehatan, kompensasi, dan kinerja karyawan CV Berkah Anugerah Abadi Kertak Hanyar Kabupaten Banjar Provinsi Kalimantan Selatan. Analisis dihitung dengan frekuensi, rata-rata, dan persentase..

2. Uji F (Simultan)

Uji $\mathrm{F}$ atau uji simultan digunakan untuk menjelaskan pengaruh simultan variabel bebas terhadap variabel terikat. Ketentuan yang digunakan adalah jika F hitung $>\mathrm{F}$ tabel dan signifikan $<0,05$ maka hipotesis yang menyatakan semua variabel bebas berpengaruh secara simultan terhadap variabel terikat diterima. Sebaliknya jika F hitung < $\mathrm{F}$ tabel dan signifikan $>0,05$ maka hipotesis yang menyatakan semua variabel bebas berpengaruh secara simultan terhadap variabel terikat ditolak.

3. Uji t (Parsial)

Uji t digunakan meramalkan pengaruh variabel bebas terhadap variabel terikat secara parsial. Kriteria untuk menentukan pengaruh parsial ini membandingkan signifikansi dengan 0,05. Jika signifikansi $<0,05$ maka pengaruh variabel bebas terhadap variabel terikat secara parsial diterima. Sebaliknya jika signifikansi $>0,05$ maka pengaruh variabel bebas terhadap variabel terikat secara parsial ditolak. Untuk meramalkan variabel yang berpengaruh dominan terhadap variabel terikat ditentukan dengan membandingkan $t$ hitung semua variabel bebas. Nilai t hitung terbesar merupakan

4. Analisis Regresi Berganda

Analisis regresi berganda merupakan perluasan dari regersi sederhana yaitu dengan menambah jumlah variabel bebas (regresi berganda) (Sanusi, 2012). Analisis regresi dilakukan dengan menggunakan aplikasi SPSS versi 20.:

$$
\mathbf{Y}=\alpha+\beta_{1} X_{1}+\beta_{2} X_{2}+\beta_{3} X_{3}+e_{i}
$$

Keterangan :

$\mathrm{Y}=$ Kinerja Karyawan

$\mathrm{X}_{1}=$ Kesehatan dan Keselamatan Kerja

$\mathrm{X}_{2}=$ Kompensasi

$\mathrm{X}_{3}=$ Motivasi

$\alpha \quad=$ Konstanta

$\beta_{1} \quad=$ Koefesien Kesehatan dan Keselamatan Kerja

$\boldsymbol{\beta}_{\mathbf{2}}=$ Koefesien Kompensasi

$\boldsymbol{\beta}_{3}=$ Koefesien Motivasi Kerja

\section{PEMBAHASAN}

$$
\mathrm{e}_{\mathrm{i}} \quad=\text { Error Term }
$$

\subsection{Hasil Analisa Data}

\section{Hasil Uji F (Simultan)}

Tabel 1

\section{Hasil Uji F}

\begin{tabular}{|c|c|c|}
\hline F Tabel & F Hitung & Sig. \\
\hline 2,68 & 3060,9 & 0,000 \\
\hline
\end{tabular}

Tabel 1 menunjukkan nilai $\mathrm{F}$ hitung hasil analisis regresi ganda 3060,9. Nilai $\mathrm{F}$ hitung 2,68 dan signifikan 0,00. Jadi $\mathrm{F}$ hitung $>\mathrm{F}$ table dan signifikan $0,00<0,05$. Jadi dapat diputuskan bahwa variabel K3 (X1), kompensasi (X2), dan motivasi kerja (X3) berpengaruh signifikan terhadap kinerja (Y) Karyawan CV Berkah Anugerah Abadi Kertak Hanyar Kabupaten Banjar Provinsi Kalimantan Selatan. Dengan demikian varibael Keselamatan dan Kesehatan Kerja, kompensasi, dan motivasi berpengaruh signifikan terhadap kinerja karyawan CV Berkah Anugerah Abadi Kertak Hanyar Kabupaten Banjar Provinsi Kalimantan Selatan diterima

\section{Hasil Uji t (Parsial)}


Tabel 2

Koefisien Regresi (B)

\begin{tabular}{|c|l|c|c|c|c|}
\hline No & Variabel & B & t & Sig & Keputusan \\
\hline 1 & Konstanta & 1,349 & - & - & - \\
\hline 2 & X1 - Y &,- 203 & $-3,164$ & 0,002 & Signifikan \\
\hline 3 & X2 - Y &, 656 & 7,294 & 0,000 & Signifikan \\
\hline 4 & X3 - Y &, 616 & 26,134 & 0,000 & Signifikan \\
\hline
\end{tabular}

Signifikan pengaruh parsial (X1-Y) K3 terhadap kinerja 0,02. Signifikan pengaruh parsial (X2Y) kompensasi terhadap kinerja 0,00. Signifikan pengaruh parsial (X3-Y) motivasi kerjaa terhadap kinerja 0,00. Keselamatan dan Kesehatan Kerja berpengaruh signifikan terhadap kinerja karyawan CV Berkah Anugerah Abadi Kertak Hanyar Kabupaten Banjar Provinsi Kalimantan Selatan. Kompensasi berpengaruh signifikan terhadap kinerja Karyawan CV Berkah Anugerah Abadi Kertak Hanyar Kabupaten Banjar Provinsi Kalimantan Selatan. Motivasi berpengaruh signifikan terhadap kinerja Karyawan CV Berkah Anugerah Abadi Kertak Hanyar Kabupaten Banjar Provinsi Kalimantan Selatan.

Variabel yang dominan mempengaruhi kinerja adalah motivasi kerja karena pengaruh motivasi kerja terhadap kinerja memiliki nilai t hitung paling besar dibandingkan dengan yang lainnya. Garis regresi dirumuskan sebagai berikut:

$$
\begin{gathered}
Y=a+b_{1} X_{1}+b_{2} X_{2}+b_{3} X_{3}+\mathrm{e} \\
\mathrm{Y}=1,349+(-2,03)+0,565 X 2+0,616 \times 3)
\end{gathered}
$$

\subsection{Pembahasan}

Hasil penelitian ini membuktikan bahwa K3 (Keselamatan dan Kesehatan Kerja), kompensasi, dan motivasi kerja berpengaruh signifikan terhadap kinerja karyawan CV Berkah Anugerah Abadi Kertak Hanyar Kabupaten Banjar Provinsi Kalimantan Selatan baik secara parsial maupun simultan. Motivasi kerja berpengaruh dominan terhadap kinerja karyawan CV Berkah Anugerah Abadi Kertak Hanyar Kabupaten Banjar Provinsi Kalimantan Selatan.

Tingkat kecelakaan yang tinggi dalam bekerja maka mengkibatkan karyawan banyak yang menderita, absensi meningkat, produksi menurun, dan biaya pengobatan semakin besar. Ini semua akan menimbulkan kerugian bagi karyawan maupun perusahaan bersangkutan, karena mungkin karyawan terpaksa berhenti bekerja sebab cacat dan perusahaan kehilangan karyawannya. Keselamatan dan Kesehatan Kerja (K3) merupakan suatu upaya untuk menciptakan suasana bekerja yang aman, nyaman, dan tujuan akhirnya adalah mencapai kinerja yang maksimal. Oleh karena itu, K3 mutlak untuk dilaksanakan pada setiap jenis bidang pekerjaan tanpa kecuali.

Upaya K3 diharapkan dapat mencegah dan mengurangi risiko. Karyawan yang terjamin keselamatan dan kesehatan kerjanya akan bekerja lebih optimal, dan ini akan berdampak pada produk yang dihasilkan. Pada gilirannya, ini akan meningkatkan kualitas produk dan jasa yang dihasilkan ketimbang sebelum dilakukan penerapan, citra organisasi terhadap kinerjanya akan semakin meningkat, dan meningkatkan kepercayaan pelanggan.

Proses penerapan sistem manajemen K3 harus dimulai dari manajemen puncak dalam perusahaan. Sebagai tahap pertama adalah memilih jenis sistem manajemen K3 yang akan diterapkan. Organisasi harus mempersiapkan sendiri untuk memenuhi persyaratan sistem manajemen K3 yang dipilih. Penetapan tujuan penerapan sistem manajemen K3 harus dinyatakan secara jelas oleh manajemen puncak. Mereka dapat membuat surat edaran atau spanduk yang nantinya disosialisasikan pada semua personel di perusahaan. Disamping tujuan penerapan sistem manajemen K3, surat edaran ini juga menyatakan ruang lingkup penerapan sistem manajemen K3.

Variabel penting lain yang perlu dipehatikan dalam organisasi atau perusahaan adalah kompensasi. Pekerjaan yang memerlukan tingkat kesukaran yang tinggi dan resiko yang berat, perlu kompensasi yang tinggi. Karyawan diberikan penghargaan finansial dan non finansial oleh organisasi berdasarkan tugas, pekerjaan, dan hasil pekerjaan yang telah telah dicapai. Kompensasi 
bisa berbentuk gaji, pemberian hari libur, dan bonus. Kompensasi diberikan sesuai dengan kinerja pegawai. Kinerja yang dicapai sesuai dengan kompensasi yang diberikan organisasi.

Selain itu faktor motivasi juga penting ditingkatkan dalam organisasi. Karyawan harus selalu dimotivasi agar kinerja yang dihasilkan meningkat. Sebab kejenuhan bekerja sering terjadi di tempat kerja. Apabila gejala ini terjadi pada diri karyawan, dapat dilihat ciri-cirinya seperti absensi (ketidak hadiran) meningkat, disiplin merosot, produktivitas menurun, labour turn over (tingkat keluar masuk karyawan) makin tinggi, ada tuntutan karyawan yang tidak henti-hentinya, sampai pada gejala pemogokan.

Motivasi berhubungan langsung dengan kinerja karyawan. Motivasi dapat dipastikan mempengaruhi kinerja, walaupun bukan satu-satunya faktor yang membentuk kinerja (Wibowo, 2011). Kebutuhan adanya kekurangan fisiologis atau psikologis yang menimbulkan perilaku.Teori motivasi berdasarkan hirarki kebutuhan dikemukakan Maslow menyatakan bahwa kebutuhan manusia berjenjang dari psysiological, safety, social, dan self actualization (Wibowo, 2011).

Motivasi kerja berkenaan dengan bagaimana cara mendorong orang bersemangat bekerja, agar mau bekerja dengan memberikan secara optimal kemampuan dan keahliannya untuk mencapai tujuan organisasi. Motivasi penting dalam peningatan kinerja karyawan karena dengan motivasi diharapkan agar setiap karyawan mau bekerja keras dan antusias untuk meningkatkan kinerja dalam rangka pencapaian tujuan organisasi secara optimal. Karyawan akan mendapatkan imbalan yang sebanding dengan hasil kerja yang dikontribusikannyan kepada pihak organisasi

\section{KESIMPULAN}

Berdasarkan hasil penelitian dan analisis yang diperoleh maka dapat ditarik beberapa kesimpulan sebagai berikut:

1. Keselamatan dan Kesehatan Kerja (K3) terlaksana dengan baik, kompensasi terlaksana dengan baik, motivasi kerja karyawan baik, dan kinerja karyawan CV Berkah Anugerah Abadi Kabupaten Banjar Provinsi Kalimantan Selatan juga mencapai kategori baik.

2. Keselamatan dan Kesehatan Kerja (K3), kompensasi, motivasi kerja berpengaruh signifikan terhadap kinerja karyawan CV Berkah Anugerah Abadi Kabupaten Banjar Provinsi Kalimantan secara parsial.

3. Keselamatan dan Kesehatan Kerja, (K3), kompensasi, motivasi kerja berpengaruh signifikan terhadap kinerja karyawan CV Berkah Anugerah Abadi Kabupaten Banjar Provinsi Kalimantan secara simultan.

4. Motivasi kerja berpengaruh dominan terhadap kinerja karyawan CV Berkah Anugerah Abadi Kabupaten Banjar Provinsi Kalimantan dibandingkan dengan K3 dan kompensasi.

\section{SARAN}

Berdasarkan hasil penelitian dan kesimpulan diberikan saran sebagai berikut:

1. Karyawan CV Berkah Anugerah Abadi Kertak Hanyar Kabupaten Banjar Provinsi Kalimantan diharapkan meningkatkan motivasi kerja karena berpengaruh terhadap peningkatan kinerja.

2. Pihak perusahaan CV Berkah Anugerah Abadi Kertak Hanyar Kabupaten Banjar Provinsi Kalimantan dibandingkan dengan K3 dan kompensasi diharapkan meningkatkan Kesehatan dan Keselamatan Kerja (K3), komopensasi, dan motivasi karyawan karena mempengaruhi peningkatan kinerja.

3. Disarankan kepada peneliti berikutnya dapat menjadikan hasil penelitian ini sebagai bahan pengkajian penelitian yang relevan. 


\section{DAFTAR PUSTAKA}

Alma, Buchari.2008. Pengantar Bisnis. Bandung: Alfabeta.

Anjani, M, Hamidah Nayati Utami, dan Arik Prasetya. 2014. Pengaruh Keselamatan dan Kesehatan Kerja terhadap Kinerja karyawan (Studi pada Karyawan Bagian Produksi PT. International Power Mitsui Operation and Maintenance Indonesia (IPMOMI) Paiton). Jurnal Administrasi Bisnis (JAB)| Vol. 9 No. 1 April 2014.

Ghozali, Imam. 2016. Aplikasi Analisis Multivariate dengan Program IMB Statistik 23. Semarang : Badan Penerbit Universitas Diponegoro.

Hafied, Hamzah. 2016. Sumber Daya Manusia. Makasar: Kretakupa.

Hameed, Abdul, dkk 2013. Impact of Compensation on Employee Performance (Empirical Evidence from Banking Sector of Pakistan). International Journal of Business and Social Science. Vol. 5 No. 2; February 2014

Haryani, Sagita Sukma, Djamhur Hamid, Heru Susilo, 2015. Pengaruh Kompensasi terhadap Motivasi Kerja dan Kinerja (Studi pada karyawan PT Telekomunikasi Indonesia Tbk Malang). Jurnal Administrasi Bisnis (JAB)|Vol. 25 No. 1 Agustus 2015|

Ilfani, G. 2013. Analisis pengaruh Keselamatan dan Kesehatan Kerja terhadap Kinerja Karyawan (Studi pada APAC Inti Corpora Bawean jawa Tengah Unit Spinning 2). Semarang: Tesis. Fakultas Ekonomi dan Bisnis Diponegoro.

Jerusalem dan Khayati. 2010. Modul Keselamatan dan Kesehatan Kerja. Yogyakarta; Universitas Negeri Yogyakarta.

Kasmir. 2011. Kewirausahaan. Jakarta : PT Raja Grafindo Persada.

Misbahuddin dan Iqbal Hasan. 2013. Analisis Data Penelitian dengan Statistik. Jakarta: Bmi Aksara.

Notoatmodjo, Soekidjo. 2009. Pengembangan Sumber Daya Manusia. Jakarta: PT Rineka Cipta. Priansa. D. J. 2014. Perencanaan dan Pengembangan SDM. Bandung: Alfabeta.

Robbins, Stephen P. 2008. Perilaku Organisasi. Jakarta : Salemba Empat.

Samsuddin, Sadli.2006. Manajemene Sumber Daya Manusia, Bandung: CV Pustaka Setia.

Sanusi, Anwar. 2012. Metodologi Penelitian Bisnis. Jakarta; Salemba Empat.

Sedarmayanti. 2009. Manajemen Sumber daya Manusia. Bandung: PT Refika Aditama

Safetysign. 2016. Bahaya Menghirup Debu Batu Bara, Pekerja Tambang Rentan Terkena Pneumokoniosis (Online). Diakses dari https://www.safetysign.co.id/news/210/BahayaMenghirup-Debu-Batu-Bara-Pekerja-Tambang-Rentan-Terkena-Pneumokoniosis.

Tanggal 18 Januari 2018.

Sudjana, Nana. 2009. Tuntunan Penyusuna Karya Ilmiah Makalah, Skripsi, tesis, dan Disertasi. Bandung: Sinar Baru A.

Sugiyono. 2008. Metode Penelitian Administrasi. Bandung: Alfabeta.

Sunyoto, Danang. 2012. Teori. Kuisioner, dan Analisis Data Sumber Daya Manusia. Yogyakarta : CAPS.

Safetysign. 2016. Bahaya Menghirup Debu Batu Bara, Pekerja Tambang Rentan Terkena Pneumokoniosis (Online). Diakses dari https://www.safetysign.co.id/news/210/BahayaMenghirup-Debu-Batu-Bara-Pekerja-Tambang-Rentan-Terkena-Pneumokoniosis.

Tanggal 18 Januari 2018.

Theodora, Olivia. 2015. Pengaruh Motivasi Kerja Terhadap Kinerja karyawan PT. Sejahtera Motor Gemilang. Journal AGORA Vol. 3, No. 2, (2015)

Tiyanto, P. 2010. Tantangan Manajemen Sumberdaya Manusia Abad 21. Semarang : Untag Triton. 2009. Mengelola Sumber Daya Manusia. Yogyakarta: Oryza.

Umar, Hasan. 2010. Desain Penelitian SDM dan Perilaku Karyawan. Jakarta: PT RajaGrafindo. Wahyuni, Y. 2011. Dasar-Dasar Statistik Deskriptif. Yogyakarta: Nuha Medika.

Wibowo. 2011. Manajemen Kinerja. Jakarta: Rajawali Pers.

Yuniarsih, Tj. dan Suwatno. 2008. Manajemen Sumber Daya Manusia. Bandung: Alfabeta.

Zeanuri, M. 2015. Manajemen SDM di Pemerintahan. Yogyakarta: LP2M Universitas Muhammadiyah Yogyakarta. 


\section{Biodata Penulis}

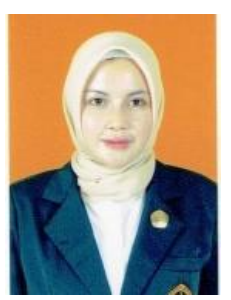

Hernilawwati, S.E., M.M, Penulis mendapatkan gelar Sarjana Ekonomi (SE) pada Sekolah Tinggi Ilmu Manajemen Indonesia (STIMI) Banjarmasin kemudian gelar Magister Manajemen (S2) pada Universitas Merdeka Malang dengan pembimbing Dr. Junianto T. Darsono, M.M dan Dr. H. Sutriswanto, SE., MM.

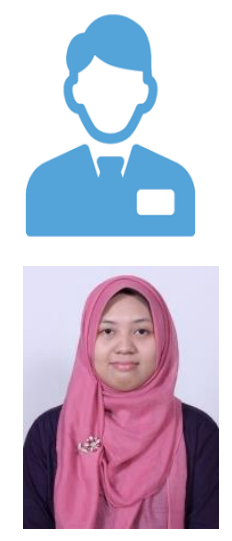

Dr. Sutriswanto, M. Si Dosen Pascasarjana Magister Manajemen, Universitas Merdeka Malang.

Devi Rusvitawati, S. Pd., M.M Lahir di Banjarmasin dan merupakan dosen muda di Program Studi Manajemen STIMI Banjarmasin. Penelitiannya lebih banyak berfokus pada Manajemen Sumber Daya Manusia.

Email: devita1412@gmail.com 